\title{
Neonatal Severe Primary Hyperparathyroidism
}

National Cancer Institute

\section{Source}

National Cancer Institute. Neonatal Severe Primary Hyperparathyroidism. NCI

Thesaurus. Code C131853.

An autosomal recessive form of Kenny-Caffey syndrome that is secondary to mutation(s) in the TCBE gene that encodes tubulin-specific chaperone $\mathrm{E}$; it is characterized by the following: hypoparathyroidism with hypocalcemia, marked growth retardation, craniofacial anomalies, absent diploic space, cortical thickening and medullary stenosis of long bones, and small hands and feet. 